\title{
Milk is not just food but most likely a genetic transfection system activating mTORC1 signaling for postnatal growth
}

\author{
Bodo C Melnik ${ }^{1 *}$, Swen Malte John ${ }^{1}$ and Gerd Schmitz ${ }^{2}$
}

\begin{abstract}
Milk has been recognized to represent a functionally active nutrient system promoting neonatal growth of mammals. Cell growth is regulated by the nutrient-sensitive kinase mechanistic target of rapamycin complex 1 (mTORC1). There is still a lack of information on the mechanisms of mTORC1 up-regulation by milk consumption. This review presents milk as a materno-neonatal relay system functioning by transfer of preferential amino acids, which increase plasma levels of glucose-dependent insulinotropic polypeptide (GIP), glucagon-like peptide-1 (GLP-1), insulin, growth hormone (GH) and insulin-like growth factor-1 (IGF-1) for mTORC1 activation. Importantly, milk exosomes, which regularly contain microRNA-21, most likely represent a genetic transfection system enhancing mTORC1-driven metabolic processes. Whereas human breast milk is the ideal food for infants allowing appropriate postnatal growth and species-specific metabolic programming, persistent high milk signaling during adolescence and adulthood by continued cow's milk consumption may promote mTORC1-driven diseases of civilization.
\end{abstract}

Keywords: Branched-chain amino acids, Diseases of civilization, Glucose-dependent insulinotropic polypeptide, Glucagon-like peptide-1, Exosomal microRNA, Leucine, MicroRNA-21, Milk, mTORC1, Postnatal growth, Tryptophan

\section{Introduction}

Milk is a highly specialized, complex nutrient system developed by mammalian evolution to promote postnatal growth. In contrast to feeding artificial infant formula, only human milk allows appropriate metabolic programming and protects against diseases of civilization in later life [1]. However, continued consumption of cow's milk and dairy products during adolescence and adulthood is an evolutionarily novel behavior that may have long-term adverse effects on human health [2]. It is the intention of this review article to unravel milk's functionality as a signaling system of evolution. The mechanisms of milk signaling presented here have been elucidated by translational research of the endocrine effects of cow's milk consumption as well as individual protein components of bovine milk (whey protein and casein) on human subjects. The crucial function of milk of all mammals is to promote postnatal growth and to assure appropriate species-specific postnatal metabolic programming. On the molecular level, cell growth, cell proliferation, protein- and lipid synthesis, anabolic metabolic processes, and inhibition of autophagy are mediated by the nutrient-sensitive kinase mechanistic target of rapamycin complex 1 (mTORC1) [3-5]. mTORC1 is activated by branched-chain amino acids, especially leucine, the most abundant amino acid of whey proteins, growth factors like insulin and insulin-like growth factor-1 (IGF-1), and sufficient cellular energy sensed by AMP-activated kinase (AMPK) $[3,5,6]$. Cow's milk (subsequently termed "milk") appears to promote mTORC1 signaling by providing amino acids that function as endocrine messengers to increase IGF-1 and insulin secretion as well as by milkderived exosomal regulatory microRNAs (miRs), especially miR-21, which attenuates the inhibitory effects of various tumor suppressor proteins like phosphatase and tensin homolog (PTEN), Sprouty 1 and 2 and programmed cell death 4 (PDCD4) on mTORC1-signaling.

\footnotetext{
* Correspondence: melnik@t-online.de

${ }^{1}$ Department of Dermatology, Environmental Medicine and Health Theory, University of Osnabrück, Sedanstrasse 115, D-49090, Osnabrück, Germany Full list of author information is available at the end of the article
} 


\section{Amino acid signaling of milk}

\section{Tryptophan-GH-IGF-1-mTORC1 pathway}

Milk provides substantial amounts of tryptophan easily hydrolyzed from $\alpha$-lactalbumin in milk's whey protein fraction. Tryptophan promotes pituitary serotonin synthesis [7], which increases growth hormone (GH) secretion [8]. GH stimulates hepatic IGF-1 synthesis. Both, GH and IGF-1 have been shown to increase by milk consumption [9]. Casein proteins are rich sources of tryptophan, too. Casein in comparison to whey protein has been shown to differentially increase hepatic IGF-1 synthesis [10]. There is substantial epidemiological evidence that milk consumption efficiently elevates IGF-1 plasma levels by 20 to $30 \%$ in comparison to non-dairy consumers [9-14].

\section{Leucine-insulin-mTORC1 pathway}

Water soluble, easily hydrolysable whey proteins in comparison to all other animal-derived structural muscle proteins provide highest amounts of the branched-chain amino acids (BCAAs) leucine, isoleucine and valine, which raise postprandial insulin plasma levels within minutes [15-17]. Furthermore, whey proteins induce the secretion of the incretin glucose-dependent insulinotropic polypeptide (GIP), which in concert with insulinotropic BCAAs costimulates insulin secretion of pancreatic $\beta$-cells $[15,16]$. Milk proteins, especially leucine, stimulate the release of the intestinal incretin glucagon-like peptide-1 (GLP-1) [18]. It has previously been shown that leucine stimulates insulin secretion by $\beta$-cells due to its metabolism by oxidative decarboxylation and the ability of leucine to allosterically activate glutamate dehydrogenase (GDH) by $\beta$-cell mitochondria [19-21]. Xu et al. [22] demonstrated that leucine induced translation initiation by phosphorylation of 4E-BP-1 (formerly termed PHAS-I) and S6K, through the mTORC1-signaling pathway of pancreatic $\beta$-cells. In $\beta$ cells, leucine activates mTORC1 $[19,20]$ that regulates insulin secretion and $\beta$-cell mass expansion [23-25]. Leucine not only increases insulin secretion but also enhances insulin signaling in insulin target tissues [26]. Chronic leucine supplementation elevated basal IRS-1 phosphorylation on tyrosine 632 and improved insulin-stimulated Akt and mTOR phosphorylation in liver, skeletal muscle and adipose tissue of rats fed a high fat diet [26]. In human skeletal muscle direct evidence has been provided that whey protein intake raised mTORC1 activity [27]. Thus, milkderived BCAAs, especially leucine, appear to function as important messengers of mammalian lactation promoting insulin secretion and $\beta$-cell mass expansion required for appropriate mTORC1-driven postnatal growth.

\section{Tryptophan-GIP-GH-IGF-1-mTORC1 pathway}

Tryptophan deficiency has profound inhibitory effects on protein synthesis, RNA translation and growth [28]. Intragastric addition of tryptophan to early-weaned piglets increased intestinal GIP secretion [29]. Whey proteins and caseins are rich protein sources of tryptophan. Test meals of $16.7 \mathrm{~g}$ and $18.2 \mathrm{~g}$ whey protein to healthy young adults substantially increased GIP secretion and postprandial plasma GIP concentrations [15,16], further supported by own data on postprandial plasma GIP levels of 10 healthy young adults ( 8 males, 2 females, mean age 25 yrs) after $30 \mathrm{~g}$ whey protein intake (Figure 1). Hydrolyzed peptides of whey protein competitively inhibit the GIP inactivating enzyme dipeptidyl peptidase IV, thereby extending GIP bioactivity [30]. GIP may not only signal via the entero-insular axis stimulating insulin secretion but also enhances $\mathrm{GH}$ secretion of the somatotroph cells of the pituitary, which express the GIP-receptor (GIPR) [31]. GIPR activation elevates cAMP, which drives GHpromoter activity [31]. Thus, GIP not only responds to dietary glucose but may function as a whey (tryptophan)dependent $\mathrm{GH}$-stimulating hormone that activates both pancreatic insulin as well as hepatic IGF-1 synthesis for mTORC1-dependent protein and lipid synthesis required for cell growth. Remarkably, deletion of tryptophan from a hepatocyte culture medium substantially decreased IGF-1 synthesis [32]. In accordance, Rich-Edwards et al. [9] demonstrated that milk consumption of children increased serum GH and IGF-1 levels and shifted the somatotropic axis to higher levels. Furthermore, it has been demonstrated in ovine hepatocyte cultures that IGF-1 synthesis clearly depends on amino acid availability in a dose dependent manner [33]. In a rat hepatocyte primary culture, IGF-1 mRNA expression was dependent on amino acid availability [34]. Furthermore, the essential amino acid content of the diet is critical for the optimal restoration of IGF-1 after fasting, when protein intake is reduced [35]. Recent evidence has been provided that post-exercise replenishment of essential amino acids plus carbohydrate significantly increased leucine and free IGF-1 serum levels of 8 young healthy males [36]. Insulin increases hepatic IGF-1 synthesis and enhances free IGF-1 bioactivity by inhibition of hepatic insulin-like growth factor-binding protein-1 (IGFBP-1) [37-39]. IGFBP-2 may be subject to dual control, with $\mathrm{GH}$ and amino acid availability serving as the primary regulators [40,41]. Thus, milk-derived amino acids provide a sophisticated regulatory network (GH, insulin and amino acids, especially leucine and tryptophan) that stimulates downstream IGF-1-signaling.

\section{Amino acid-IGF-1-insulin-mTORC1 pathway promoting cell growth}

As demonstrated above milk-derived amino acids upregulate the secretory activity of the pituitary gland ( $\mathrm{GH}$ secretion), the liver (IGF-1 secretion), the pancreatic $\beta$-cells (insulin secretion), the intestinal enteroendocrine K-cells (GIP secretion), and L-cells (GLP-1 secretion). Milk proteins in comparison to all other animal proteins provide the 


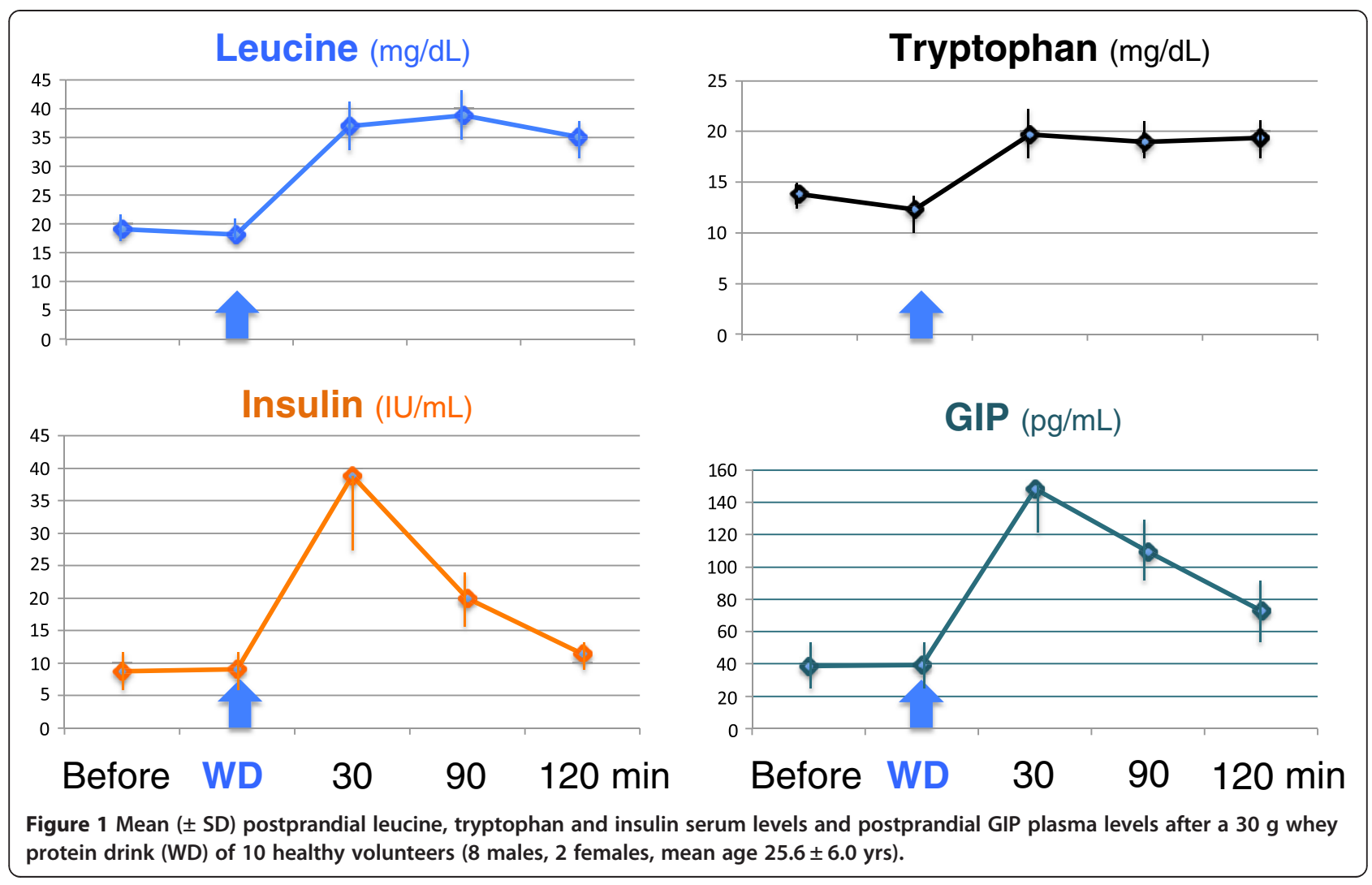

highest postprandial levels of the BCAAs leucine, isoleucine and valine $[15,16,42]$. Milk-driven insulin/IGF-1 signaling combined with leucine abundance provides optimal conditions for up-regulation of mTORC1 mediating accelerated growth and proliferation of peripheral cells of the milk recipient. Persistent milk consumption and dairy-enriched Western diet thus represents a fundamental stimulus for continued mTORC1 activation with all its adverse consequences in adolescence and adulthood [43].

\section{MicroRNA signaling of milk \\ The role of milk's exosomal microRNAs}

Secreted microRNAs (miRs) represent a newly recognized most important layer of gene regulation in eukaryocytes, which plays a relevant role for intercellular communication $[44,45]$. miRs bind through partial sequence homology to the 3 '-untranslated region of target mRNAs and cause either translational block or less frequently mRNA degradation [46]. miRs that are enclosed by membranous microvesicles, so-called exosomes, play a pivotal role for horizontal miR transfer [47]. Intriguingly, breast milk contains the highest concentration of total RNAs $(47,240 \mu \mathrm{g} / \mathrm{L})$ in comparison to other body fluids like plasma $(308 \mu \mathrm{g} / \mathrm{L})$ [48]. There is accumulating evidence that bovine and human milk transfer substantial amounts of miRs for regulatory functions by exosomal transport [49-51]. Chen et al. [50] have detected 245 miRs in cow's milk. They reported relatively high and consistent expression of seven miRs in mature cow's milk at various lactation periods listed from highest to lowest sequencing frequencies: miR-21 $(24,137)$, miR-99a (24,097), miR-148a (16,597), miR-30d (14,089), miR-200c (11,010), miR-26b $(6,595)$ and miR-26a $(3,376)$, respectively [50]. In cow's milk, whey and bovine colostrum, miR-containing exosomes of 50-100 nm have been identified [52-54].

Milk exosomal miRs are of functional importance for the development and maturation of the neonate's immune system [54-56]. These findings implicate that exosomal miRs of milk may reach the systemic circulation and organ systems. The exosome lipid membrane protects milkderived miRs against degradation. Remarkably, miRs of cow's milk are resistant against acidic conditions ( $\mathrm{pH} 2)$ as well as heat exposure and external RNAse treatment [51], most likely withstanding the harsh degrading conditions in the gastrointestinal tract. Although, raw milk contains the highest amounts of total miRs, pasteurized commercial milk and milk powder still contain substantial and stable concentrations of miRs [50]. It has already been suggested that, milk-derived exosomes may pass the intestinal barrier and reach the systemic circulation [51]. Intestinal cells release exosomes of 30-90 $\mathrm{nm}$ in diameter from their apical and basolateral sides [57]. The tetraspanin CD63, a known exosome marker of cow's milk exosomes [52], is present on intestinal epithelial-derived exosomes [57]. CD63- and 
CD81-containing tetraspanin molecules have been detected on exosomes in human plasma [58]. In fact, blood is regarded as a physiological fluid for exosome circulation in the body, pointing to the important role of exosomes as carriers for cell-cell or organ-organ communications [58-60]. Furthermore, bovine milk's predominant miR species, miR-21, is a major component of human plasma [61]. Thus, it is conceivable that milk's exosomal miRs reach the plasma compartment to function as a messenger system promoting postnatal growth. In fact, it has already been demonstrated that a diet-derived miR, the plant MIR168a, reaches the plasma compartment of human subjects and affects LDLRAP1 metabolism in the liver [62]. Thus, there is good reason to assume that cow's milk-derived miRs affect distant regulatory networks and organs of the milk recipient. A systemic transfer of milkderived miRs to the neonate or the persistent milk consumer may augment mTORC1-mediated growth signaling, which is a physiologically required process for postnatal growth and development but not for humans after the lactation period.

\section{Potential role of milk miR-21 for the augmentation of mTORC1 signaling}

Exosomal miR-21, a consistent component of cow's milk and human breast milk [50,56], appears to play a key role in mTORC1 signaling. Critical targets of miR-21 are mRNAs of important tumor suppressor proteins involved in upstream and downstream suppression of mTORC1 signaling, i.e., PTEN [63-66], Sprouty1 and Sprouty2 [67-69], PDCD4 [70-72] (Figure 2). Furthermore, miR-21 has been shown to induce the cell cycle promoter cyclin D1 in an mTORC1-dependent manner [73]. Supposed that milk-derived miR-21 reaches distant cells of the milk recipient, PTEN suppression could increase insulin/IGF-1/PI3K/Akt signaling, which further augments mTORC1 activation. miR-21-induced inhibition of Sprouty1 and 2 would amplify Ras-Raf-MEKERK signaling, which additionally suppresses TSC2 and thus raises mTORC1 activity (Figure 2). Furthermore, miR-21 could stimulate the initiation of translation by repression of PDCD4, which is a suppressor of translation initiation that inhibits the RNA helicase eIF4A [74]. Both, 4E-BP-1 and PDCD4 are crucial regulatory inhibitors of translation initiation and thus of protein synthesis. Activation of the mTORC1 pathway and its substrate kinase S6K1 results in subsequent phosphorylation of 4E-BP-1 and PDCD4 that promote eIF4E-eIF4G complex assembly and stimulate mRNA translation [74]. miR-21-mediated suppression of PDCD4 expression may further amply translation initiation, a reasonable regulatory step of milk signaling to promote postnatal growth. In this regard, miR-21 signaling of milk appears to enhance upstream and downstream mTORC1 signaling.
Thus, milk appears to combine both amino acid- and miR-mediated pathways to optimize mTORC1 signaling for the promotion of postnatal growth. However, it is of critical concern that miR-21 is a well-known oncogene, which by suppressing various tumor suppressor genes plays a key role in resisting programmed cell death [75]. In comparison to amino acid signaling of milk, which primarily affects layers of posttranslational modifications, miR signaling of milk may represent an even more powerful archaic regulatory network, because it interferes with posttranscriptional regulation of numerous genes and gene networks. In fact, miR-21 has been shown to contribute to renal cancer cell proliferation and migration via activation of mTORC1 [76].

\section{Milk signaling and the promotion of diseases of civilization}

There is accumulating evidence that chronic diseases of civilization are associated with increased mTORC1 signaling $[77,78]$, like acne $[79,80]$, obesity $[81,82]$, type 2diabetes [77,83], arterial hypertension [84], Alzheimer's disease [85], cancer [86], especially prostate cancer $[87,88]$. Thus, cow's milk is not just a simple food for humans, but a tremendously powerful evolutionary program of the faster growing species Bos taurus, which may permanently over-stimulate mTORC1 signaling in human milk consumers. In this regard the milk kinship hypothesis appears in a new light, which explains the increased risk for genetic disease in offspring of marriages of "milk siblings", who were breastfed by the same woman (forbidden by the Qur'an in countries of the Middle East) [89]. Thus, we are at the beginning to ask for the metabolic consequences of bovine milk-derived miRs on human subjects during various phases of human growth and development.

\section{Milk-mediated mTORC1-activation, adipogenesis and insulin resistance}

Further research should investigate the precise trafficking of milk exosomes, which most likely reach the systemic circulation of the milk recipient. Continued mTORC1activation by milk-derived exosomal transfer of miR-21 may represent a persistently adverse health effect of regular milk and dairy product intake, which may play an important role for the development and progression of mTORC1-driven diseases of civilization [77-88]. In analogy to the postulated Trojan exosome hypothesis explaining the role of exosomes for the spread of RNA viruses [90], the milk exosome system too appears to function as a Trojan horse "transfecting" the neonate's metabolism to ensure species-specific mTORC1-driven growth and anabolism.

There is accumulating evidence that milk consumption in children, adolescents and adults increases body mass index (BMI) [81-83,91-93] and induces insulin resistance in children [17]. In Nordic countries, where women 
regularly consume milk during pregnancy, increased infant birthweights related to dairy protein intake during pregnancy have been reported $[94,95]$.

In comparison to all other structural animal proteins, whey proteins provide highest amounts of most easily hydrolysed BCAAs [42], which raise postprandial plasma BCAA levels within minutes $[15,16]$. Thus, other high BCAA sources like muscle proteins of beef differ from soluble milk proteins, especially whey, by a more retarded release of BCAAs into the systemic circulation. In fact, beef has an insulinemic index of 51 [96], whereas insulin scores for milk and milk products range from 89 to 115 [96,97]. Increased BCAA plasma levels in children and adolescents have recently been associated with increased risk for elevated BMI, insulin resistance and type 2 diabetes mellitus $[98,99]$. However, the most striking difference between milk and muscle or plant proteins is the high amount of specific exosomal miRs, like miR-21 and miR-103 [50,51], that may play an important role as an additional layer of metabolic regulation.

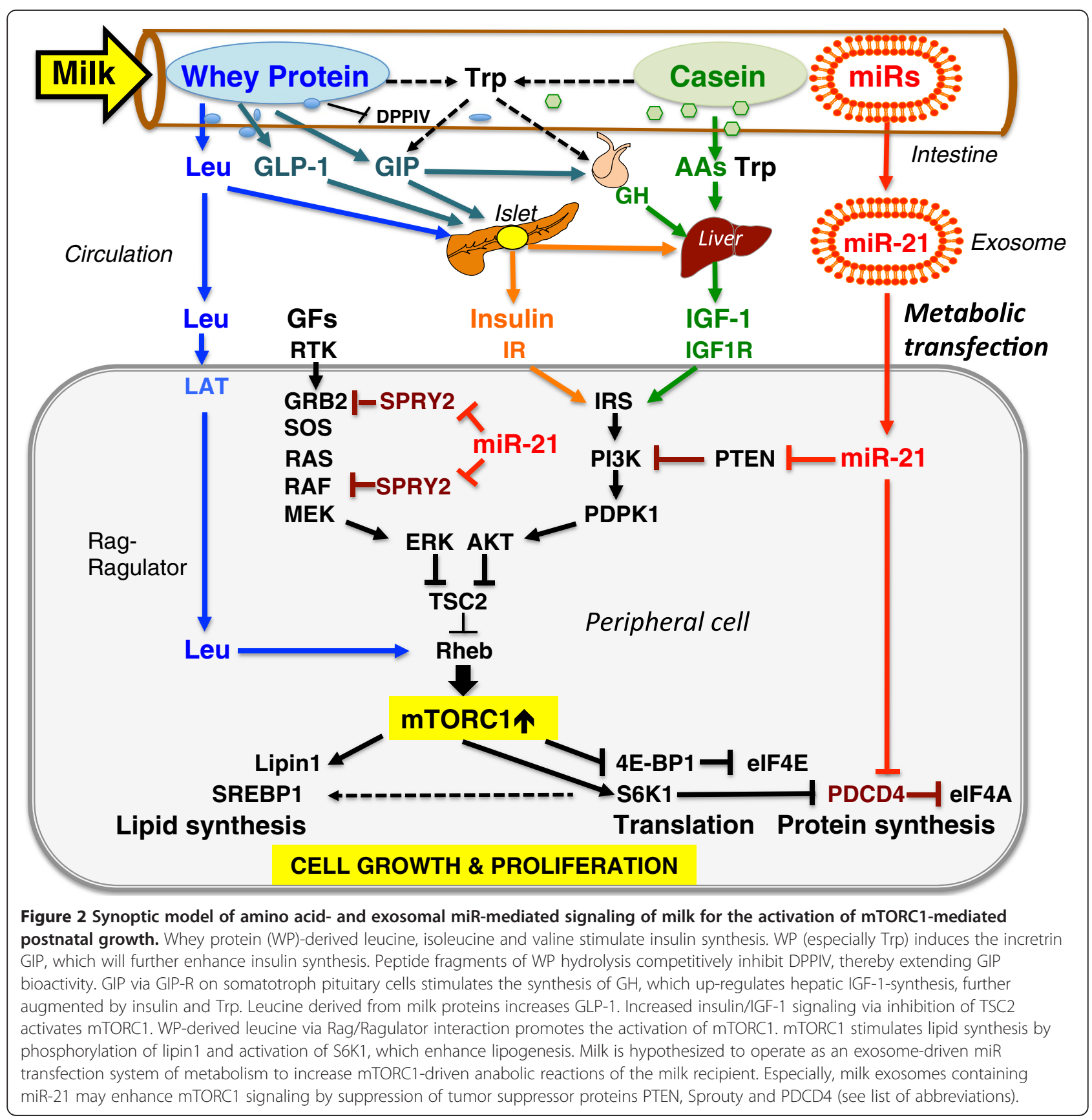


Potential role of milk-derived miRs in metabolic regulation There is accumulating evidence that miRs are highly connected nodes in regulatory networks underlying adipogenesis and adipose dysfunction in obesity [100]. Kim et al. [101] demonstrated that miR-21 regulates adipogenic differentiation in mesenchymal stem cells derived from human adipose tissue. The same group observed a correlation between miR-21 levels and adipocyte number in white adipose tissue (WAT) of high fat-diet induced obese mice [102]. The later study suggests that miR-21 may control the proliferation of adipocyte precursors [102]. There is further compelling evidence that adipogenesis depends on mTORC1 signaling [103]. As miR-21 reduces the expression of various tumor suppressor genes of the mTORC1 signaling pathway, milk-derived exosomal miR-21 may promote adipogenesis. In fact, genetic deletion of S6K1 in mice $\left(\mathrm{S} 6 \mathrm{~K} 1^{-/-}\right.$mice), the downstream target of mTORC1, inhibited the transformation of mesenchymal stem cells into adipocytes and reduced the total number and size of adipocytes [104]. Ectopic expression of miR-103 in preadipocytes accelerated adipogenesis as measured by both the up-regulation of many adipogenesis markers and by an increase in triglyceride accumulation at an early stage of adipogenesis [105]. miR-103 is a component of cow's milk [51] (Table 1).

Insulin-induced gene 1 (insig-1) mRNA is a validated target of miR-29a [106], a further miR detected in cow's milk [54]. Insig-1 binds sterol regulatory element-binding protein (SREBP) cleavage-activating protein in the endoplasmic reticulum, thereby blocking proteolytic processing required for SREBP activation [107]. Insig-1 restricts lipogenesis in mature adipocytes and inhibits differentiation in preadipocytes [108]. Inactivation of insig-1 mRNA by milk-derived miR-29a may thus be another potential mechanisms by which milk consumption my promote adipogensis and BMI increase as observed in children, adolescents and adults [81-83,91-93].

Remarkably, cow's milk contains substantial amounts of miR-155 [51]. The target of miR-155 is the adipogenic transcription factor CCAAT/enhancer-binding protein $\beta(\mathrm{C} / \mathrm{EBP} \beta)$. Overexpression of miR-155 in mice has been shown to reduce brown adipose tissue (BAT) mass [109]. Thus, milk miR-155 intake may attenuate thermogenesis of BAT, an unfavorable condition promoting lipid and energy storage in WAT promoting obesity. However, attenuation of BAT thermogenesis may be a developmentally appropriate postnatal event.

Elevated plasma BCAAs have been associated with reduced cellular BCAA utilization and/or incomplete BCAA oxidation [110]. The mitochondrial BCAA oxidation checkpoint, which commits BCAAs to degradation is the branched-chain $\alpha$-ketoacid dehydrogenase (BCKD) complex. BCKD activity is reduced in WAT of obese individuals [110]. miR-29b is targeted to the mRNA for the dihydrolipoamide branched chain acyltransferase component of BCKD and prevents translation when bound [111]. Thus, miR-29b inhibits the pathway of BCAA catabolism. Intriguingly, miR-29b is a major miR of bovine milk [51]. Milk's miR-29b may thus function to maintain high plasma BCAAs levels important for mTORC1dependent growth and appropriate amino acid uptake for protein de novo biosynthesis of functional and structural proteins required for postnatal growth. High plasma levels of milk-derived BCAAs together with milk-miR29b-mediated inhibition of BCAA catabolism may thus over-activate mTORC1-S6K1 signaling. Insulin resistance during mTORC1-driven phases of growth may represent a negative feedback mechanism, induced by up-regulated S6K1, which via IRS-1 phosphorylation inhibits downstream insulin signaling [112]. These metabolic events may explain the link between elevated BCAA plasma levels and insulin resistance [113]. In fact, Hoppe et al. demonstrated that milk consumption but not meat (which misses miR-29b) induced insulin resistance in Danish prepubertal boys [17]. Thus, milk, the starter kit of mammalian evolution, appears to execute a highly sophisticated metabolic program, which orchestrates BCAA-, miR-21and miR-29b-driven mTORC1-mediated protein biosynthesis. In synergy with activated protein biosynthesis, the

Table 1 Selected milk-derived miRs and their potential impact on metabolism

\begin{tabular}{|c|c|c|c|}
\hline Milk-derived miR & Ref. & miR function in metabolism & Ref. \\
\hline \multirow[t]{2}{*}{ miR-21 } & 50 & miR-21: Inhibition of various tumor suppressor gene mRNAs (PTEN, Spouty1, Sprouty2, PDCD4) & {$[63-72,75]$} \\
\hline & & Increased adipogenesis & {$[100-102]$} \\
\hline \multirow[t]{2}{*}{ miR-29a } & 54 & miR-29a: Down-regulation of Insig-1 with increased lipogenesis and adipocyte differentiation & {$[106]$} \\
\hline & & & {$[107,108]$} \\
\hline \multirow[t]{2}{*}{ miR-29b } & 51 & miR-29b: Reduction of BCKD and reduced BCAA catabolism & {$[111]$} \\
\hline & & & {$[110]$} \\
\hline miR-103 & 51 & miR-103: Increased adipogenesis & {$[100,105]$} \\
\hline miR-155 & 51 & miR-155: Reduction of brown adipose tissue and thermogenesis & {$[109]$} \\
\hline Let-7a, b, c, f & 51 & Let-7: overexpression results in insulin resistance and disturbed glucose homeostasis & {$[120,122]$} \\
\hline
\end{tabular}


mTORC1-driver milk should promote lipid synthesis too. Remarkably, it has recently been recognized that activated mTORC1 induces the expression of key transcription factors of lipogenesis, sterol response element binding protein-1 (SREBP-1) [4,114-116], and peroxisome proliferator-activated receptor- $\gamma$ (PPAR $\gamma)[117,118]$. Furthermore, activated mTORC1 has been shown to suppress lipolysis, stimulates lipogenesis and promotes fat storage [119]. Thus, milk appears to provide an endocrine signaling environment for increased mTORC1-driven lipogenesis and fat storage as well as miR-155-induced suppression of BAT differentiation resulting in BMI elevations and fat deposition in WAT [81-83,91-93].

Milk contains substantial amounts of let7a, let7b, let7c and let7f [50]. There is accumulating evidence that the Lin28/let-7 axis regulates glucose metabolism [120]. Muscle specific loss of Lin28a and overexpression of let-7 resulted in insulin resistance and impaired glucose tolerance in mice [120]. Intriguingly, let-7 targets are enriched for genes that contain SNPs associated with type 2 diabetes and fasting glucose in human genome-wide association studies [120]. Lin28, a developmentally regulated RNA-binding protein, selectively blocks the processing of pri-let-7 miRs [121]. Notably, the restoration of the Lin28 protein blocked let-7 expression and restored glucose metabolism in adipose-derived stem cells derived from obese tissues [122]. The most interesting miRs in inflammatory microvesicles in association with metabolic and cardiovascular diseases recently reported are the let-7 family, miR17/92 family, miR-21, miR-29, miR-126, miR-133, miR-146 and miR-155 [123]. Notably, there is a substantial overlap with miRs derived from milk exosomes (Table 1).

\section{Conclusions and future perspectives}

Routine milk consumption, which has been boosted by the introduction of refrigeration technology in the early 1950 's, is an evolutionarily novel dietary behavior of Homo sapiens of the Neolithic period, which may have adverse long-term biological consequences [2]. Milk is not just food but appears to represent a most sophisticated endocrine signaling system activating mTORC1 via special maternal milk-derived dietary messengers controlled by the mammalian lactation genome: BCAAs of milk proteins and exosomal miRs produced by the mammary gland, which appear to augment mTORC1 signaling for postnatal growth. In this regard, it is of critical concern that persistently increased mTORC1 signaling has been recognized as the fundamental driving force for the development of mTORC1-driven diseases of civilization [77-83]. Therefore, future research in nutrition science should pay special attention to the function of milk-derived BCAAs and furthermore should clarify the potential role of milk's exosomal miR-transfer on metabolic regulation in the milk recipient. The potential uptake of labeled exosomal miRs derived from commercial milk has to be studied in animal models and humans in greater detail.

\section{Abbreviations}

AAs: Amino acids; AMP: Adenosine monophosphate; AMPK: AMP-activated protein kinase; Akt: V-AKT murine thymoma viral oncogene homolog (protein kinase B); BAT: Brown adipose tissue; BCAA: Branched-chain amino acid; BCKD: Branched-chain a-ketoacid dehydrogenase; BMI: Body mass index; C/EBPß: CCAAT/enhancer-binding protein $\beta$; DPPIV: Dipeptidyl peptidase IV; 4E-BP-1: Eukaryotic translation initiation factor 4E-binding protein 1; elF4A: Eukaryotic translation initiation factor 4A; elF4E: Eukaryotic translation initiation factor 4E; ERK: Mitogen-activated protein kinase kinase 4 GDH: Glutamate dehydrogenase; GF: Growth factors; GH: Growth hormone; GHR: Growth hormone receptor; GIP: Glucose-dependent insulinotropic polypeptide; GIPR: GIP receptor; GLP-1: Glucagon-like peptide-1; GRB2: Growth factor receptor-bound protein 2; IGF-1: Insulin-like growth factor-1; IGF1R: Insulin-like growth factor-1 receptor; IR: Insulin receptor; IRS: Insulin receptor substrate; PI3K: Phosphoinositide-3 kinase; LAT: L-type amino acid transporter; Leu: Leucine; miR: micro-ribonucleic acid; MEK: Mitogen-activated protein kinase kinase 1; mTORC1: Mechanistic (mammalian) target of rapamycin complex 1; PDCD4: Programmed cell death 4; PDPK1: 3-Phosphoinositide-dependent protein kinase 1; PTEN: Phosphatase and tensin homolog; RTK: Receptor tyrosine kinase; Raf: V-RAF-1 murine leukemia viral oncogene homolog; Ras: V-HA-RAS rat sarcoma viral oncogene homolog; Rheb: Ras homolog enrich in brain; S6K1: Ribosomal protein S6 kinase, 70-kD kinase 1; SOS: Son of sevenless; SPRY2: Sprouty2; Trp: Tryptophan; SREBP-1: Sterol regulatory element-binding transcription factor 1; TSC2: Tuberin; WAT: White adipose tissue.

\section{Competing interests}

The authors declare that they have no competing interests.

\section{Authors' contributions}

BCM wrote the manuscript and formulated the hypothesis of milk exosomal miR-mediated transfection of metabolism of the milk recipient. GS evaluated postprandial plasma parameters after whey protein challenge of human volunteers, researched data and contributed to the discussion and conclusions. BCM and SMJ both performed the whey protein study with 10 healthy volunteers. All authors read and approved the final manuscript.

\section{Author details}

${ }^{1}$ Department of Dermatology, Environmental Medicine and Health Theory, University of Osnabrück, Sedanstrasse 115, D-49090, Osnabrück, Germany. ${ }^{2}$ Institute of Clinical Chemistry and Laboratory Medicine, University Clinics of Regensburg, Josef-Strauss-Allee 11, D-93053, Regensburg, Germany.

Received: 5 May 2013 Accepted: 23 July 2013

Published: 25 July 2013

\section{References}

1. Ip S, Chung M, Raman G, Chew P, Magula N, DeVine D, Trikalinos T, Lau J: Breastfeeding and maternal and infant health outcomes in developed countries. Evid RepTechnol Assess (Full Rep) 2007, 153:1-186.

2. Wiley AS: Cow milk consumption, insulin-like growth factor-l, and human biology: a life history approach. Am J Hum Biol 2012, 24:130-138.

3. Dodd KM, Tee AR: Leucine and mTORC1: a complex relationship. Am Physiol Endocrinol Metab 2012, 302:E1329-E1342.

4. Bakan I, Laplante M: Connecting mTORC1 signalling to SREBP-1 activation. Curr Opin Lipidol 2012, 23:226-234.

5. Foster KG, Fingar DC: Mammalian target of rapamycin (mTOR): conducting the cellular signalling symphony. J Biol Chem 2010, 285:14071-14077.

6. Wu G: Amino acids: metabolism, functions, and nutrition. Amino Acids 2009, 37:1-17.

7. Markus CR: Dietary amino acids and brain serotonin function; implications for stress-related affective changes. Neuromol Med 2008, 10:247-258.

8. Lancranjan I, Wirz-Justice A, Pühringer W, del Pozo E: Effect of 1-5 hydroxytryptophan infusion on growth hormone and prolactin secretion in man. J Clin Endocrinol Metab 1977, 45:588-593. 
9. Rich-Edwards JW, Ganmaa D, Pollak MN, Nakamoto EK, Kleinman K, Tserendolgor U, Willet WC, Frazier AL: Milk consumption and the prepubertal somatotropic axis. Nutr J 2007, 6:28.

10. Hoppe C, Mølgaard C, Dalum C, Vaag A, Michaelsen KF: Differential effects of casein versus whey on fasting plasma levels of insulin, IGF-1 and IGF-1/IGFBP-3: results from a randomized 7-day supplementation study in prepubertal boys. Eur J Clin Nutr 2009, 63:1076-1083.

11. Norat T, Dossus L, Rinaldi S, Overvad K, Grønbaek H, Tjønneland A, Olsen A Clavel-Chapelon F, Boutron-Ruault MC, Boeing H, Lahmann PH, Linseisen J, Nagel G, Trichopoulou A, Trichopoulos D, Kalapothaki V, Sieri S, Palli D, Panico S, Tumino R, Sacerdote C, Bueno-de-Mesquita HB, Peeters PH, van Gils CH, Agudo A, Amiano P, Ardanoz E, Martinez C, Quirós R, Tormo MJ, et al.: Diet, serum insulin-like growth factor-I and IGF-binding protein-3 in European women. Eur J Clin Nutr 2007, 61:91-98.

12. Crowe FL, Key TJ, Allen NE, Appleby PN, Roddam A, Overvad K, Grønbaek H, Tjønneland A, Halkjaer J, Dossus L, Boeing H, Kröger J, Trichopoulou A, Dilis V, Trichopoulos D, Boutron-Ruault MC, De Lauzon B, Clavel-Chapelon F, Palli D, Berrino F, Panico S, Tumino R, Sacerdote C, Bueno-de-Mesquita HB, Vrieling A, van Gils $\mathrm{CH}$, Peeters PH, Gram IT, Skeie G, Lund E, et al.: The association between diet and serum concentrations of IGF-I, IGFBP-1, IGFBP-2, and IGFBP-3 in the European Prospective Investigation into Cancer and Nutrition. Cancer Epidemiol Biomarkers Prev 2009, 18:1333-1340.

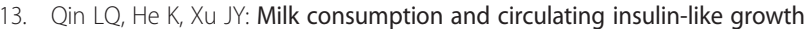
factor-I level: a systematic literature review. Int J Food Sci Nutr 2009, 60(Suppl 7):330-340

14. Socha P, Grote V, Gruszfeld D, Janas R, Demmelmair H, Closa-Monasterolo R, Subías JE, Scaglioni S, Verduci E, Dain E, Langhendries JP, Perrin E, Koletzko B, European Childhood Obesity Trial Study Group: Milk protein intake, the metabolic-endocrine response, and growth in infancy: data from a randomized clinical trial. Am J Clin Nutr 2011, 94(Suppl 6):1776S-1784S.

15. Nilsson M, Stenberg M, Frid AH, Holst JJ, Björck IM: Glycemia and insulinemia in healthy subjects after lactose-equivalent meals of milk and other food proteins: the role of plasma amino acids and incretins. Am J Clin Nutr 2004, 80:1246-1253.

16. Salehi A, Gunnerud U, Muhammed SJ, Ostman E, Holst JJ, Björck I, Rorsman P. The insulinogenic effects of whey protein is partially mediated by a direct effect of amino acids and GIP on $\beta$-cells. Nutr Metab (Lond) 2012, 9:48.

17. Hoppe C, Mølgaard C, Vaag A, Barkholt V, Michaelsen KF: High intakes of milk, but not meat, increases s-insulin and insulin resistance in 8-yearold boys. Eur J Clin Nutr 2005, 59:393-398.

18. Chen $\mathrm{Q}$, Reimer RA: Dairy protein and leucine alter GLP-1 release and mRNA of genes involved in intestinal lipid metabolism in vitro. Nutrition 2009, 25:340-349.

19. Sener A, Malaisse WJ: L-leucine and a nonmetabolized analogue activate pancreatic islet glutamate dehydrogenase. Nature 1980, 288:187-189.

20. Malaisse WJ: Branched-chain amino and keto acid metabolism in pancreatic islets. Adv Enzyme Regul 1986, 25:203-217.

21. Fahien LA, MacDonald MJ, Kmiotek EH, Mertz RJ, Fahien CM: Regulation of insulin release by factors that also modify glutamate dehydrogenase. J Biol Chem 1988, 263:13610-13614.

22. Xu G, Kwon G, Cruz WS, Marshall CA, McDaniel MK: Metabolic regulation by leucine of translation initiation through the mTOR-signaling pathway by pancreatic $\beta$-cells. Diabetes 2001, 50:353-360.

23. McDaniel ML, Marshall CA, Pappan KL, Kwon G: Metabolic and autocrine regulation of the mammalian target of rapamycin by pancreatic $\beta$-cells. Diabetes 2002, 51:2877-2885.

24. Yang J, Chi Y, Burkhardt BR, Guan Y, Wolf BA: Leucine metabolism in regulation of insulin secretion from pancreatic beta cells. Nutr Rev 2010, 68:270-279.

25. Le Bacquer O, Queniat G, Gmyr V, Kerr-Conte J, Lefebvre B, Pattou F: mTORC1 and mTORC2 regulate insulin secretion through Akt in INS-1 cells. J Endocrinol 2013, 216:21-29.

26. Li X, Wang X, Liu R, Ma Y, Guo H, Hao L, Yao P, Liu L, Sun X, He K, Cao W, Yang $X$ : Chronic leucine supplementation increases body weight and insulin sensitivity in rats on high-fat diet likely by promoting insulin signalling in insulin-target tissues. Mol Nutr Food Res 2013, 57:1067-1079.

27. Farnfield MM, Carey KA, Gran P, Trenerry MK, Cameron-Smith D: Whey protein ingestion activates $\mathrm{mTOR}$-dependent signalling after resistance exercise in young men: a double-blinded randomized controlled trial. Nutrients 2009, 1:263-275.

28. Ponter AA, Cortamira NO, Sève B, Salter DN, Morgan LM: The effects of energy source and tryptophan on the rate of protein synthesis and on hormones of the entero-insular axis in the piglet. Br J Nutr 1994, 71:661-674.

29. Ponter AA, Sève B, Morgan LM: Intragastric tryptophan reduces glycemia after glucose, possibly via glucose-mediated insulinotropic polypeptide in early-weaned piglets. J Nutr 1994, 124:259-267.

30. Gunnarsson TP, Sörhed Winzell M, Deacon CF, Larson MO, Jelic K, Carr RD, Ahrén B: Glucose-induced incretin hormone release and inactivation are differently modulated by oral fat and protein in mice. Endocrinology 2006 , 147:3173-3180.

31. Occhi G, Losa M, Albiger N, Trivellin G, Regazzo D, Scanarini M, MonteserinGarcia JL, Fröhlich B, Ferasin S, Terreni MR, Fassina A, Vitiello L, Stalla G, Mantero F, Scaroni C: The glucose-dependent insulinotropic polypeptide receptor is overexpressed amongst GNAS1 mutation-negative somatotropinomas and drives growth hormone (GH)-promoter activity in GH3 cells. J Neuroendocrinol 2011, 23:641-649.

32. Harp JB, Goldstein S, Phillips LS: Nutrition and somatomedin. XXIII. Molecular regulation of IGF-1 by amino acid availability in cultured hepatocytes. Diabetes 1991, 40:95-101.

33. Wheelhouse NM, Stubbs AK, Lomax MA, MacRae JC, Hazlerigg DG: Growth hormone and amino acid supply interact synergistically to control insulin-like growth factor-I production and gene expression in cultured ovine hepatocytes. J Endocrinol 1999, 163:353-361

34. Thissen JP, Pucilowska JB, Underwood LE: Differential regulation of insulinlike growth factor I (IGF-I) and IGF binding protein-1 messenger ribonucleic acids by amino acid availability and growth hormone in rat hepatocyte primary culture. Endocrinology 1994, 134:1570-1576.

35. Thissen JP, Ketelslegers JM, Underwood LE: Nutritional regulation of the insulin-like growth factors. Endocr Rev 1994, 15:80-101.

36. Foster EB, Fisher G, Sartin JL, Elsasser TH, Wu G, Cowan W, Pascoe DD: Acute regulation of IGF-1 by alterations in post-exercise macronutrients. Amino Acids 2012, 42:1405-1416.

37. Patel S, Lochhead PA, Rena G, Fumagalli S, Pende M, Kozma SC, Thomas G, Sutherland C: Insulin regulation of insulin-like growth factor-binding protein-1 gene expression is dependent on the mammalian target of rapamycin, but independent of ribosomal $\mathbf{6} 6$ kinase activity. J Biol Chem 2002, 277:9889-9895.

38. Lee PDK, Conover CA, Powell DR: Regulation and function of insulin-like growth factor-binding protein-1. Proc Soc Exp Biol Med 1993, 204:4-29.

39. Frost RA, Lang CH: Differential effects of insulin-like growth factor-1 (IGF- I) and IGF-binding protein-1 on protein metabolism in human skeletal muscle cells. Endocr Soc 1999, 140:3962-3970.

40. Smith WJ, Underwood LE, Clemmons DR: Effects of caloric or protein restriction on insulin-like growth factor-I (IGF-I) and IGF-binding proteins in children and adults. J Clin Endocrinol Metab 1995, 80:443-449.

41. Rivero LGF, Martin MA, Arahuetes R, Hernandez ER, Pascual-Leone AM: Effects of refeeding of undernourished and insulin treatment of diabetic neonatal rats on IGF and IGFBP. Am J Physiol 1996, 271:E223-E231.

42. Millward DJ, Layman DK, Tomé D, Schaafsma G: Protein quality assessment: impact of expanding understanding of protein and amino acid needs for optimal health. Am J Clin Nutr 2008, 87:1576S-1581S.

43. Melnik BC, John SW, Schmitz G: Over-stimulation of insulin/IGF-1 signalling by Western diet may promote diseases of civilization: lessons learnt from Laron syndrome. Nutr Metab (Lond) 2011, 8:41.

44. Liang H, Huang L, Cao J, Zen K, Chen X, Zhang CY: Regulation of mammalian gene expression by exogenous microRNAs. WIRES RNA 2012 3:733-742.

45. Chen $X$, Liang $H$, Zhang J, Zen $K$, Zhang CY: Secreted microRNAs: a new form of intercellular communication. Trends Cell Biol 2012, 22:125-132.

46. Ambros $V$ : The functions of animal microRNAs. Nature 2004, 431:350-355

47. Chen $\mathrm{X}$, Liang $\mathrm{H}$, Zhang J, Zen $\mathrm{K}$, Zhang $\mathrm{CY}$ : Horizontal transfer of microRNAs: molecular mechanisms and clinical applications. Protein Cell 2012, 3:28-37.

48. Weber JA, Baxter DH, Zhang S, Huang DY, Huang KH, Lee MJ, Galas DJ, Wang K: The mircoRNA spectrum in 12 body fluids. Clin Chem 2010, 56:1733-1741.

49. Hata T, Murakami K, Nakatani H, Yamamoto Y, Matsuda T, Aoki N: Isolation of bovine milk-derived microvesicles carrying mRNA and microRNAs. Biochem Biophys Res Commun 2010, 396:528-533.

50. Chen X, Gao C, Li H, Huang L, Sun Q, Dong Y, Tian C, Gao S, Dong H, Guan D, Hu X, Zhao S, Li L, Zhu L, Yan Q, Zhang J, Zen K, Zhang CY: Identification and characterization of microRNAs in raw milk during 
different periods of lactation, commercial fluid, and powdered milk products. Cell Res 2010, 20:1128-1137.

51. Izumi H, Kosaka N, Shimizu T, Sekine K, Ochiya T, Takase M: Bovine milk contains microRNA and messenger RNA that are stable under degradative conditions. J Dairy Sci 2012, 95:4831-4841.

52. Reinhardt TA, Lippolis JD, Nonnecke BJ, Sacco RE: Bovine milk exosome proteome. J Proteomics 2012, 75:1486-1492.

53. Izumi H, Kosala N, Shimizu T, Sekine K, Ochiya T, Takase M: Purification of RNA from milk whey. Methods Mol Biol 2013, 1024:191-201.

54. Sun Q, Chen X, Yu J, Ken K, Zhang CY, Li L: Immune modulatory function of abundant immune-related microRNAs in microvesicles from bovine colostrum. Protein Cell 2013, 4:197-210.

55. Kosaka N, Izumi H, Sekine K, Ochiya T: microRNA as a new immuneregulatory agent in breast milk. Silence 2010, 1:7.

56. Zhou Q, Li M, Wang X, Li Q, Wang T, Zhu Q, Zhou X, Wang X, Gao X, Li X: Immune-related microRNAs are abundant in breast milk exosomes. Int Biol Sci 2012, 8:118-123.

57. Van Niel G, Raposo G, Candahl C, Boussac M, Hershberg R, Cerf-Bensussan $\mathrm{N}$, Heyman M: Intestinal epithelial cells secrete exosome-like vesicles. Gastroenterology 2001, 121:337-349

58. Caby MP, Lankar D, Vincendeau-Scherrer C, Raposo G, Bonnerot C Exosomal-like vesicles are present in human blood plasma. Int Immunol 2005, 17:879-887.

59. Ludwig AK, Giebel B: Exosomes: small vesicles participating in intercellular communication. Int J Biochem Cell Biol 2012, 44:11-15.

60. Corrado C, Raimondo S, Chiesi A, Ciccia F, De Leo G, Alessandro R: Exosomes as intercellular signalling organelles involved in health and disease: basic science and clinical applications. Int J Mol Sci 2013, 14:5338-5366.

61. Olivieri F, Spazzafumo L, Santini G, Lazzarini R, Albertini MC, Rippo MR, Galeazzi R, Abbatecola AM, Marchesellli F, Monti D, Ostan R, Cevenini E, Antonicelli R, Franceschi C, Procopio AD: Age-related differences in the expression of circulating microRNAs: miR-21 as a new circulating marker of inflammaging. Mech Ageing Dev 2012, 133:675-685.

62. Zhang L, Hou D, Chen X, Li D, Zhu L, Zhang Y, Li J, Bian Z, Liang X, Cai X, Yin Y, Wang C, Zhang T, Zhu D, Zhang D, Xu J, Chen Q, Ba Y, Liu J, Wang Q, Chen J, Wang J, Wang M, Zhang Q, Zhang J, Zen K, Zhang CY: Exogenous plant MIR168a specifically targets mammalian LDLRAP1: evidence of cross-kingdom regulation by microRNA. Cell Res 2012, 22:107-126.

63. Meng F, Henson R, Wehbe-Janek H, Ghoshal K, Jacob ST, Patel T: MicroRNA21 regulates expression of the PTEN tumor suppressor gene in human hepatocellular cancer. Gastroenterology 2007, 133:647-658.

64. Han M, Liu M, Wang Y, Chen X, XU J, Sun Y, Zhao L, Qu H, Fan Y, Wu C: Antagonism of miR-21 reverses epithelial-mesenchymal transition and cancer stem cell phenotype through AKT/ERK $1 / 2$ incactivation by targeting PTEN. PLoS One 2012, 7:e39520.

65. Dey N, Das F, Mariappan MM, Mandal CC, Ghosh-Choudhury N, Kasinath BS, Choudhury GG: MicroRNA-21 orchestrates high glucose-induced signals to TOR complex 1, resulting in renal cell pathology in diabetes. J Biol Chem 2011, 286:25586-25603.

66. Dey N, Ghosh-Choudhury N, Kasinath BS, Choudhury GG: TGF $\beta$-stimulated microRNA-21 utilizes PTEN to orchestrate AKT/mTORC1 signaling for mesangial cell hypertrophy and matrix expansion. PLoS One 2012, 7:e42316

67. Sayed D, Rane S, Lypowy J, He M, Chen IY, Vashistha H, Yan L, Malhotra A, Vatner D, Abdellatif M: MicroRNA-21 targets Sprouty2 and promotes cellular outgrouths. Mol Biol Cell 2008, 19:3272-3282

68. Dariminpourain M, Wang S, Ittmann M, Kwabi-Addo B: Transcriptional and post-transcriptional regulation of Sprouty1, a receptor tyrosine kinase inhibitor in prostate cancer. Prostate Cancer Prostatic Dis 2011, 14:279-285.

69. Frey MR, Carraro G, Batra RK, Polk DB, Warburton D: Sprouty keeps bowel kinases regular in colon cancer, while miR-21 targets Sprouty. Cancer Biol Ther 2011, 11:122-124.

70. Asangani IA, Rasheed SA, Nikolova DA, Leupold JH, Colburn NH, Post S, Allgayer H: MicroRNA-21 (miR-21) post-transcriptionally downregulates tumor suppressor Pdcd4 and stimulates invasion, intravasation and metastasis in colorectal cancer. Oncogene 2008, 27:2128-2136.

71. Lu Z, Liu M, Stribinskis V, Klinge CM, Ramos KS, Colburn NH, Li Y: MicroRNA21 promotes cell transformation by targeting the programmed cell death 4 gene. Oncogene 2008, 27:4373-4379.

72. Carayol N, Katsoulidis E, Sassano A, Altman JK, Druker BJ, Platanias LC: Suppression of programmed cell death 4 (PDCD4) protein expression by
BCR-ABL-regulated engagement of the mTOR/p70 S6 kinase pathway. J Biol Chem 2008, 283:8601-8610.

73. Ng R, Song G, Roll GR, Frandsen NM, Willenbring H: A microRNA-21 surge facilitates rapid cyclin D1 translation and cell cycle progression in mouse liver regeneration. J Clin Invest 2012, 122:1097-1108.

74. Dennis MD, Jefferson LS, Kimball SR: Role of p70S6K1-mediated phosphorylation of elF4B and PDCD4 proteins in the regulation of protein synthesis. J Biol Chem 2012, 287:42890-42899.

75. Becker Buscaglia LE, Li Y: Apoptosis and the target genes of miR-21. Chin J Cancer 2011, 30:371-380.

76. Dey N, Das F, Ghosh-Choudhury N, Mandal CC, Parekh DJ, Block K, Kasinath BS, Abboud HA, Chouldhury GG: MicroRNA-21 governs TORC1 activation in renal cancer cell proliferation and invasion. PLoS One 2012, 7:e37366.

77. Zoncu R, Efeyan A, Sabatini DM: mTOR: from growth signal integration to cancer, diabetes and ageing. Nat Rev Mol Cell Biol 2011, 12:21-35.

78. Proud CG: mTOR signalling in health and disease. Biochem Soc Trans 2011, 39:431-436.

79. Melnik BC: Dietary intervention in acne. Attenuation of increased mTORC1 signaling promoted by Western diet. Dermatoendocrinol 2012, 4:20-32.

80. Melnik BC, Zouboulis CC: Potential role of FoxO1 and mTORC1 in the pathogenesis of Western diet-induced acne. Exp Dermatol 2013, 22:311-315.

81. Melnik BC: Excessive leucine-mTORC1-signalling of cow milk-based infant formula: the missing link to understand early childhood obesity. J Obes 2012, 2012:197653.

82. Arnberg K, Mølgaard C, Michaelsen KF, Jensen SM, Trolle E, Larnkjær A: Skim milk, whey, and casein increase body weight and whey and casein increase plasma C-peptide concentration in overweight adolescents. J Nutr 2012, 142:2083-2090.

83. Melnik BC: Leucine signalling in the pathogenesis of type 2 diabetes and obesity. World J Diabetes 2012, 3:38-53.

84. Harlan SM, Guo DF, Morgan DA, Fernandes-Santos C, Rahmouni K Hypothalamic mTORC1 signalling controls sympathetic nerve activity and arterial pressure and mediates leptin effects. Cell Metabol 2013, 17:599-606.

85. Oddo S: The role of mTOR signaling in Alzheimer disease. Front Biosci 2012, 4:941-952

86. Pópulo $H$, Lopes $J M$, Soares $P$ : The mTOR signalling pathway in human cancer. Int J Mol Sci 2012, 13:1886-1918.

87. Hsieh AC, Liu Y, Edlind MP, Ingolia NT, Janes MR, Sher A, Shi EY, Stumpf CR, Christensen C, Bonham MJ, Wang S, Ren P, Martin M, Jessen K, Feldman ME, Weissman JS, Shokat KM, Rommel C, Ruggero D: The translational landscape of mTOR signalling steers cancer initiation and metastasis. Nature 2012, 485:55-61.

88. Melnik BC, John SM, Carrera-Bastos P, Cordain L: The impact of cow's milkmediated mTORC1-signaling in the initiation and progression of prostate cancer. Nutr Metab (Lond) 2012, 9:74.

89. Ozkan H, Tuzun F, Kumral A, Duman N: Milk kinship hypothesis in light of epigenetic knowledge. Clin Epigenetics 2012, 4(1):14.

90. Gould SJ, Booth AM, Hildreth JEK: The Trojan exosome hypothesis. Proc Natl Acad Sci USA 2003, 100:10592-10597.

91. Wiley AS: Dairy and milk consumption and child growth: Is BMI involved? An analysis of NHANES 1999-2004. Am J Hum Biol 2010, 22:517-525.

92. Berkey CS, Rocket HRH, Willet WC, Colditz GA: Milk, dairy fat, dietary calcium, and weight gain. Arch Pediatr Adolesc Med 2005, 159:543-550.

93. Barr SI, McCarron DA, Heaney RP, Dawson-Hughes B, Berga SL, Stern JS, Oparil S: Effects of increased consumption of fluid milk on energy and nutrient intake, body weight, and cardiovascular risk factors in healthy older adults. Am J Diet Assoc 2000, 100:810-817.

94. Olsen SF, Halldorsson TI, Willett WC, Knudsen VK, Gillman MW, Mikkelsen TB, Olsen J, NUTRIX Consortium: Milk consumption during pregnancy is associated with increased infant size at birth: prospective cohort study. Am J Clin Nutr 2007, 86:1104-1110.

95. Brantsaeter AL, Olafsdottir AS, Forsum E, Olsen SF, Thorsdottir I: Does milk and dairy consumption during pregnancy influence fetal growth and infant birthweight? A systematic literature review. Food Nutr Res 2012, 56:20050

96. Holt S, Brand Miller J, Petocz P: An insulin index of foods: the insulin demand generated by 1000-kJ portions of common foods. Am J Clin Nutr 1997, 66:1264-1276

97. Hoyt G, Hickey MS, Cordain L: Dissociation of the glycaemic and insulinaemic responses to whole and skimmed milk. Br J Nutr 2005, 93:175-177. 
98. Morris C, O'Grada C, Ryan M, Roche HM, Gibney MJ, Gibney ER, Brennan L: The relationship between $\mathrm{BMI}$ and metabolomic profiles: a focus on amino acids. Proc Nutr Soc 2012, 71:634-638.

99. McCormack SE, Shaham O, McCarthy MA, Deik AA, Wang TJ, Gerszten RE, Clish CB, Mootha VK, Grinspoon SK, Fleischman A: Circulating branchedchain amino acid concentrations are associated with obesity and future insulin resistance in children and adolescents. Pediatric Obesity 2013, 8:52-61.

100. Romao JM, Jin W, Dodson MV, Hausman GJ, Moore SS, Guan LL: MicroRNA regulation in mammalian adipogenesis. Exp Biol Med 2011, 236:997-1004.

101. Kim YJ, Hwang SJ, Bae YC, Jung JS: Mir-21 regulates adipogenic differentiation through the modulation of TGF- $\beta$ signalling in mesenchymal stem cells derived from human adipose tissue. Stem Cells 2009, 27:3093-3102.

102. Kim YJ, Hwang SH, Cho HH, Shun KK, Bae YC, Jung JS: MicroRNA 21 regulates the proliferation of human adipose tissue-derived mesenchymal stem cells and high-fat diet-induced obesity alters microRNA 21 expression in white adipose tissues. J Cell Physiol 2011, 227:183-193.

103. Yoon MS, Zhang C, Sun Y, Schoenherr CJ, Chen J: Mechanistic target of rapamycin (mTOR) controls homeostasis of adipogenesis. J Lipid Res 2013, 54:2166-2173.

104. Carnevalli LS, Masuda K, Frigerio F, Le Bacquer O, Um SH, Gandin V, Topisirovic I, Sonenberg N, Thomas G, Kozma SC: S6K1 plays a critical role in early adipocyte differentiation. Dev Cell 2010, 18:763-774.

105. Xie H, Lim B, Lodish H: MicroRNAs induced during adipogenesis that accelerate fat cell development are downregulated in obesity. Diabetes 2009, 58:1050-1057.

106. Zhao C, Dong J, Jiang T, Shi Z, Yu B, Zhu Y, Chen D, Xu J, Huo R, Dai J, Xia $Y$, Pan S, Hu Z, Sha J: Early second-trimenster serum miRNA profiling predicts gestational diabetes mellitus. PLoS One 2011, 6:e23925.

107. Dong $X Y$, Tang SQ: Insulin-induced gene: a new regulator in lipid metabolism. Peptides 2010, 31:2145-2150.

108. Li J, Takaishi K, Cook W, McCorkle SK, Unger RU: Insig-1 "brakes" lipogenesis in adipocytes and inhibits differentiation of preadipocytes. Proc Natl Acad Sci USA 2003, 100:9476-9481.

109. Chen Y, Siegel F, Kipschull S, Haas B, Fröhlich H, Meister G, Pfeifer A: miR155 regulates differentiation of brown and beige adipocytes via a bistable circuit. Nat Commun 2013, 4:1769.

110. Lackey DE, Lynch CJ, Olson KC, Mostaedi R, Ali M, Smith WH, Karpe F, Humphreys S, Bedinger DH, Dunn TN, Thomas AP, Oort PJ, Kieffer DA, Amin R, Bettaieb A, Haj FG, Permana P, Anthony TG, Adams SH: Regulation of adipose branched-chain amino acid catabolism enzyme expression and cross-adipose amino acid flux in human obesity. Am J Physiol Endocrinol Metab 2013, 304:E1175-E1187.

111. Mersey BD, Jin P, Danner DJ: Human microRNA (miR29b) expression controls the amount of branched chain a-ketoacid dehydrogenase complex in a cell. Hum Mol Genet 2005, 14:3371-3377.

112. Um SH, D'Alession D, Thomas G: Nutrient overload, insulin resistance, and ribosomal protein S6 kinase 1, S6K1. Cell Metab 2006, 3:393-402.

113. Lu J, Xie G, Jia W, Jia W: Insulin resistance and the metabolism of branched-chain amino acids. Front Med 2013, 7:53-59.

114. Porstmann T, Santos CR, Lewis C, Griffiths B, Schulze A: A new player in the orchestra of cell growth: SREBP activity is regulated by mTORC1 and contributes to the regulation of cell and organ size. Biochme Soc Trans 2009, 37:278-283.

115. Laplante M, Sabatini DM: An emerging role of mTOR in lipid biosynthesis. Curr Biol 2009, 19:R1046-R1052.

116. Peterson TR, Sengupta SS, Harris TE, Carmack AE, Kang SA, Balderas E, Guertin DA, Madden KL, Carpenter AE, Finck BN, Sabatini DM: mTOR complex 1 regulates Lipin1 localization to control the SREBP pathway. Cell 2011, 146:408-420.

117. Kim JE, Chen J: Regulation of peroxisome proliferator-activated receptor$\gamma$ activity by mammalian target of rapamycin and amino acids in adipogenesis. Diabetes 2004, 53:2748-2756.

118. Blanchard FG, Festuccia WT, Houde VP, St-Pierre P, Brule S, Turcotte V, Cote $\mathrm{M}$, Bellamnn K, Marette A, Deshaies Y: Major involvement of mTOR in the PPARY-induced stimulation of adipose tissue lipid uptake and fat accretion. J Lipid Res 2012, 53:1117-1125.

119. Chakrabarti P, English T, Shi J, Smas CM, Kandror KV: Mammalian target of rapamycin complex 1 suppresses lipolysis, stimulates lipogenesis, and promotes fat storage. Diabetes 2010, 59:775-781.
120. Zhu H, Shyh-Chang N, Segrè AV, Shinoda G, Shah SP, Einhorn WS, Takeuchi A, Engreitz JM, Hagan JP, Kharas MG, Urbach A, Thornton JE, Triboulet R, Gregory RI, DIAGRAM Consortium, MAGIC Investigators, Altshuler D, Daley GQ: The Lin28/let-7 axis regulates glucose metabolism. Cell 2011, 147:81-94.

121. Viswanathan SR, Dalex GQ, Gregory RI: Selective blockade of microRNA processing by Lin-28. Science 2008, 320:97-100.

122. Pérez LM, Bernal A, San Martin N, Lorenzo M, Fernández-Veledo S, Gávez BG: Metabolic rescue of obese adipose-derived stem cells by Lin28/Let7 pathway. Diabetes 2013, 62:2368-2379.

123. Hulsmans $M$, Holvoet $P$ : MicroRNA-containing microvesicles regulating inflammation in association with atherosclerotic diesease. Cardiovasc Res 2013. June 16 [Epub ahead of print]

doi:10.1186/1475-2891-12-103

Cite this article as: Melnik et al:: Milk is not just food but most likely a genetic transfection system activating mTORC1 signaling for postnatal growth. Nutrition Journal 2013 12:103.

\section{Submit your next manuscript to BioMed Central and take full advantage of:}

- Convenient online submission

- Thorough peer review

- No space constraints or color figure charges

- Immediate publication on acceptance

- Inclusion in PubMed, CAS, Scopus and Google Scholar

- Research which is freely available for redistribution

Submit your manuscript at www.biomedcentral.com/submit
C Biomed Central 